\title{
Peningkatan Hasil Belajar IPS Materi Masalah Sosial dengan Menggunakan Metode Inkuiri Pada Siswa Kelas III UPTD SD Negeri 06 Sialang Kecamatan Kapur Ix Semester I Tp 2019/2020
}

\author{
SYAPRIN \\ Guru UPTD SDN 06 Sialang Kecamatan Kapur IX \\ Email:
}

\begin{abstract}
ABSTRAK
Penelitian ini dilatar belakangi oleh adanya kenyataan di lapangan pembelajaran di kelas III Sekolah Dasar (SD) belum menggunakan metode inkuiri, Berdasarkan pengamatan peneliti di UPTD SD Negeri 06 Sialang Kecamatan Kapur IX bahwa guru kelas III SD mengajarkan IPS masih dengan cara yang sama seperti berceramah dengan arti kata pembelajaran terfokus pada guru dan siswa tidak aktif dalam pembelajaran. Tujuan penelitian ini adalah mendeskripsikan dan mendapatkan informasi tentang pembelajaran IPS dengan menggunakan metode Inkuiri untuk meningkatkan hasil belajar IPS yang meliputi(1) perencanaan, (2) pelaksanaan yang terdiri dari kegiatan awal, kegiatan inti, dan kegiatan akhir, dan (3) hasil belajar. Penelitian dilaksanakan dalam dua siklus, dilakukan secara kolaboratif antara peneliti dan guru. Data penelitian ini berupa informasi tentang data hasil tindakan yang diperoleh dari hasil pengamatan, hasil observasi aktivitas guru dan siswa, tes awal dan tes akhir pembelajaran. Subjek penelitian ini adalah siswa kelas III SD terteliti yang berjumlah 18 orang. Setelah data terkumpul data disesuaikan dengan teknik kualitatif. Hasil penelitian Pada pra siklus jumlah siswa yang mencapai KKM adalah 22,22\% atau hanya 4 siswa saja. Pada siklus I dengan metode inkuiri jumlah siswa yang mencapai KKM adalah 10 orang siswa dengan jumlah 55,56\% dengan rata-rata 70,83. Hasil belajar siswa sangat meningkat pada siklus II yaitu 18 orang siswa atau $100 \%$ yang tuntas mempelajari materi masalah sosial dengan metode inkuiri dengan rata-rata 80,83. Aktivitas guru yang berlangsung pada siklus I diperoleh skor 76 dengan rata-rata 3,45 tergolong dalam kategori baik, sedangkan pada siklus II mengalami peningkatan dengan skor 90 dan rata-rata 4,09 tergolong dalam kategori sangat baik. Aktivitas siswa selama kegiatan belajar mengajar berlangsung pada siklus I memperoleh skor 49 dengan ratarata 2,45 termasuk dalam kategori kurang, sedangkan pada siklus II mengalami peningkatan dengan skor 70 dan rata-rata 3,50 tergolong dalam katagori sangat baik.
\end{abstract}

Kata Kunci: Metode Inkuiri, Hasil Belajar Siswa,

\section{PENDAHULUAN}

\section{Latar Belakang}

Pendidikan merupakan proses budaya untuk meningkatkan harkat dan martabat manusia, melalui proses yang panjang dan berlangsung sepanjang hayat. Dalam makna sederhana pendidikan juga dapat diartikan sebagai usaha manusia untuk membina kepribadiannya sesuai dengan nilai-nilai dalam masyarakat dan kebudayaan. Dengan demikian bagaimanapun sederhananya peradaban suatu masyarakat di dalamnya pasti terjadi atau berlangsung suatu proses pendiidikan. Pendidikan merupakan fenomena manusia yang fundamental dan mempunyai sifat konstruktif dalam hidup manusia. Karena itulah kita dituntut untuk

mampu mengadakan refleksi ilmiah tentang pendidikan tersebut sebagai pertanggungjawaban terhadap perbuatan yang dilakukan, yaitu mendidik dan dididik.

Secara historis, pendidikan jauh lebih tua daripada ilmu pendidikan, sebab pendidikan sudah ada sejak adanya manusia. Sedangkan ilmu pendidikan baru lahir kira-kira pada abad ke 19. Sebelum adanya ilmu pendidikan, manusia melakukan tindakan mendidik didasarkan atas pengalaman, instuisi, dan kebijakan.

Berbagai upaya dilakukan untuk membangun pendidikan, khususnya pendidikan 9 tahun. 
Penataran, pengembangan dan pemantapan pemerolehan kesempatan wajib belajar serta peningkatan mutu pendidikan. Perlu adanya dukungan atau kerjasama yang baik antara semua komponen yang terlibat dalam dunia pendidikan. Karena dengan adanya kerjasama yang baik maka semua akan berjalan dengan lancar sesuai dengan yang diinginkan. Untuk mencapai pendidikan 9 tahun seorang siswa perlu adanya dukungan dari sekitarnya, diantaranya orang tua sebagai motivator yang utama. Dengan ini diharapkan siswa dapat lebih termotivasi untuk belajar.

Dalam proses belajar mengajar, ada empat komponen penting yang berpengaruh bagi keberhasilan siswa dalam belajar, yaitu: bahan ajar, suasana belajar, media dan sumber belajar serta guru sebagai subyek belajar. Komponenkomponen tersebut sangat penting dalam proses belajar, sehingga melemahnya satu komponen dapat menghambat tercapainya tujuan belajar yang optimal. Media dan sumber belajar yang dipilih atas dasar tujuan dan bahan pelajaran yang ditetapkan. Kompetensi guru dalam pelaksanaan interaksi belajar mengajar mempunyai beberapa indicator, diantaranya: mampu membuka pelajaran, mampu menyajikan materi, mampu menggunakan metode dan setrategi, mampu menggunakan media dan alat peraga, mampu menggunakan bahasa yang komunikatif, mampu memotifasi siswa, mampu mengorganisasi kegiatan, mampu menyimpulkan pelajaran, mampu memberikan umpan balik, mampu melaksanakan penelitian, dan mampu menggunakan waktu dengan baik

Ilmu Pengetahuan Sosial (IPS) merupakan salah satu mata pelajaran yang mengkaji seperangkat peristiwa, fakta, konsep, dan generalisasi yang berkaitan dengan isu sosial. Pendidikan IPS mempunyai peran untuk membantu siswa menjadi anggota masyarakat yang berguna dan efektif, membantu siswa mengembangkan keterampilan berpikir intelektual, keterampilan akademis, serta tanggap dan peka terhadap kemajuan IPTEK dan mampu memanfaatkannya. Sedangkan materi IPS di SD merupakan pengetahuan yang berasal dari disiplin ilmu-ilmu sosial. sistem pengetahuan yang terpadu yang bahan kajiannya sejarah, geoggrafi, ekonomi, politik, sosiologi, antropologi, psikologi, dan ekologi. Melalui mata pelajaran IPS di SD, siswa diharapkan memiliki pengetahuan dan wawasan tentang konsep-konsep dasar IPS, yang bertujuan membina sikap mental positif siswa dalam memecahkan masalah serta persoalan hidup.

Berdasarkan pengamatan peneliti pada siswa kelas III SD Negeri 06 Sialang Kecamatan Kapur IX tempat peneliti mengajar, dalam melaksanakan proses pembelajaran IPS terlihat siswa: kurang terlibat dalam pemecahan masalah dalam pembelajaran, lebih banyak menjadi pendengar guru, belum terlatih menggali dan menemukan jawaban dari permasalahan, kurang mendapat pengalaman belajar menarik. Kenyataan di atas berdampak terhadap rendahnya hasil belajar siswa pada pembelajaran IPS, rendahnya hasil belajar siswa dapat dilihat dari nilai rata-rata ulangan harian siswa dari 18 orang siswa kelas III UPTD SD Negeri 06 Sialang Kecamatan Kapur IX yaitu 56,11 atau $22,22 \%$ dari KKM yang telah ditetapkan 70. Dari rata-rata nilai tersebut terlihat bahwa siswa kelas III UPTD SD Negeri 06 Sialang Kecamatan Kapur IX belum mencapai KKM.

Agar tercapainya tujuan IPS yang telah dikemukakan diatas, salah satunya dapat dicapai dengan menggunakan metode inkuiri, karena penggunaan metode inkuiri akan menggiring siswa berfikir kritis. Menurut Mulyasa (2003:234) "metode inkuiri adalah metode yang mampu menggiring siswa menemukan sendiri atau mengalami proses mental itu sendiri, guru hanya membimbing dan memberikan instruksi" jadi metode inkuiri adalah metode mengajar yang menggiring siswa belajar sendiri dengan mengembangkan kekreatifan dalam pemecahan masalah melalui bimbingan guru. Sedangkan pendapat Kunandar (2008:372) bahwa "inkuiri melatih siswa memecahkan masalah, membuat keputusan, dan memperoleh keterampilan". Penggunaan metode inkuiri pada mata pelajaran IPS dapat dilakukan dengan melibatkan siswa berfikir dan berperan aktif dalam proses pembelajaran sehingga pembelajaran menjadi lebih menarik dan bermakna bagi siswa.

$$
\text { Penggunaan metode inkuiri dalam }
$$
pembelajaran IPS dapat menggiring siswa 
berfikir kritis dengan membimbing siswa mengemukakan ide-ide guna menemukan jawaban dari masalah yang ada, selain itu metode inkuiri dapat menumbuhkan sikap dan keterampilan sosial siswa yang mengacu pada pengambilan keputusan terhadap masalah yang dihadapi.

Berdasarkan latar belakang permasalahan diatas, peneliti merasa tertarik untuk memperbaiki proses pembelajaran dengan melakukan suatu penelitian tindakan kelas tentang "Peningkatan Hasil Belajar IPS Materi Masalah Sosial Dengan Menggunakan Metode Inkuiri Pada Siswa Kelas III UPTD SD Negeri 06 Sialang Kecamatan Kapur IX Semester I TP 2017/2018".

\section{Tujuan Penelitian}

Penelitian tindakan kelas ini bertujuan untuk mengetahui peningkatan hasil belajar IPS materi masalah sosial dengan menggunakan metode inkuiri pada siswa kelas III UPTD SD Negeri 06 Sialang Kecamatan Kapur IX.

\section{METODE PENELITIAN}

\section{Lokasi Penelitian}

Penelitian ini dilaksanakan di Kelas III UPTD SD Negeri 06 Sialang Kecamatan Kapur IX

\section{Subjek Penelitian}

Subjek pada penelitian ini adalah siswa kelas III UPTD SD Negeri 06 Sialang Kecamatan Kapur IX yang berjumlah 18 orang.

\section{Waktu / Lama Penelitian}

Penelitian ini dilaksanakan pada semester I Tahun Ajaran 2019/ 2020 dalam rentang waktu Oktober hingga Desember 2019.

\section{Rancangan Penelitian}

1. Pendekatan dan Jenis Penelitian

Penelitian ini merupakan penelitian tindakan kelas dengan menggunakan pendekatan kualitatif, jenis penelitian yang dilakukan merupakan penelitian tindakan kelas (action research) dibidang pendidikan dan pengajaran IPS. Dalam penelitian tindakan kelas diadakan perlakuan tertentu yang didasarkan pada masalah-masalah aktual yang ditemukan di lapangan. Penelitian ini berkenaan dengan perbaikan atau peningkatan proses pembelajaran IPS pada suatu kelas.
Adapun jenis peneletian yang peneliti gunakan adalah Penelitian tindakan kelas yang dilaksanakan menggunakan model siklus yang dikembangkan oleh Kemmis dan Mc Taggart (Dalam Rita 2008:45). Model siklus ini mempunnyai empat komponen yaitu perencanaan, tindakan, pengamatan dan refleksi. Penelitian ini direncanakan terdiri dari dua siklus yaitu siklus pertama dan kedua. Satu siklus berisi empat komponen, setiap siklus diadakan satu kali pertemuan, dan pada setiap akhir siklus dilakukan tes hasil tindakan. Pada setiap pertemuan dilakukan pengamatan terhadap aktifitas siswa, setelah akhir setiap siklus dilakukan tes hasil belajar.

\section{Alur Penelitian}

Penelitian tindakan kelas yang dilaksanakan menggunakan model siklus yang dikembangkan oleh Kemmis ( dalam Ritawati, 2007:21). Model siklus ini mempunnyai empat komponen yaitu perencanaan, tindakan, pengamatan dan refleksi. Penelitian ini dilaksanakan dua siklus yaitu siklus pertama, dan kedua. Satu siklus berisi empat komponen, setiap siklus diadakan dua kali pertemuan, dan pada setiap akhir akhir siklus dilakukan tes hasil belajar. Pada setiap pertemuan dilakukan pengamatan terhadap aktifitas siswa selama proses pembelajaran. Setelah akhir setiap siklus dilakukan tes hasil belajar. Untuk lebih jelasnya dapat dilihat dalam bagan berikut.

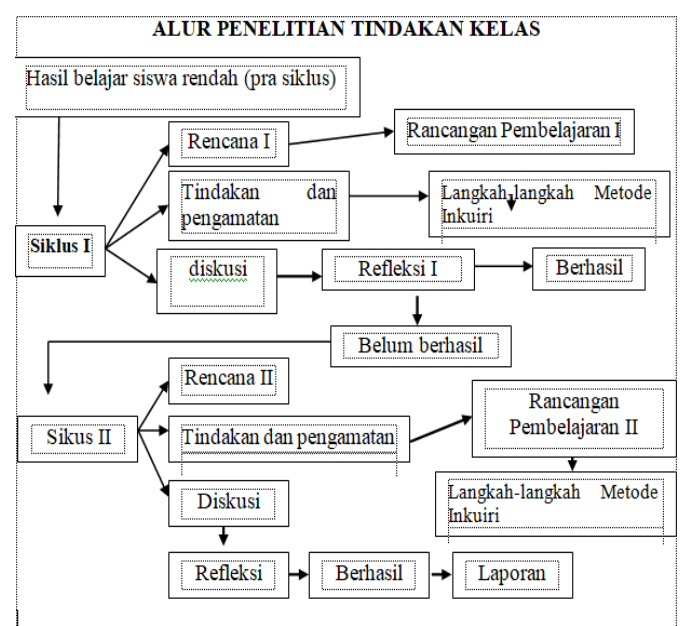

3. Prosedur Penelitian

a. Perencanaan

Sesuai dengan rumusan masalah hasil studi pendahuluan peneliti bersama guru membuat rencana tindakan yang akan dilakukan. 
Tindakan itu berupa pembelajaran IPS dengan menggunakan Metode Inkuiri dengan materi masalah sosial.

Kegiatan ini dimulai dengan merumuskan rancangan tindakan pembelajaran IPS berdasarkan Metode Inkuiri yaitu dengan kegiatan sebagai berikut:

1) menetapkan jadwal selama penelitian,

2) menyiapkan buku yang relevan

3) menyusun rancangan tindakan berupa Rencana Pelaksanaan Pembelajaran (RPP), hal ini meliputi: standar kompetensi, kompetensi dasar, indikator, materi, metode, kegiatan pembelajaran, media/sumber, evaluasi/penilaian,

4) membuat soal-soal yang akan dipergunakan dalam proses pembelajaran IPS,

5) Menyusun lembaran observasi untuk mencatat aktifitas siswa,

6) mendiskusikan dengan guru kelas tentang tata cara pengumpulan data dalam pelaksanaan observasi saat kegiatan dilakukan, agar tidak terjadi penyimpangan dalam pengambilan data. Waktu yang digunakan untuk berdiskusi adalah waktu luang yang ada bagi guru misalnya pada jam istirahat, pada waktu pelajaran agama dan olah raga, atau juga diakhir jam pelajaran.

b. Pelaksanaan

Tahap ini dimulai dengan pelaksanaan pembelajaran IPS dengan penggunaan metode Inkuiri sesuai dengan rencana yang telah disusun. Penelitian ini dilaksanakan dalam dua siklus, masing-masing siklus diadakan dua kali pertemuan sesuai dengan rencana pembelajaran yang telah disusun dan diakhir siklus dilakukan tes hasil belajar.

c. Pengamatan

Pengamatan terhadap tindakan pembelajaran IPS dikelas III dengan metode Inkuiri tentang masalah social dilakukan bersamaan dengan pelaksanaan tindakan. Hal ini dilaksanakan secara intensif, objektif, dan sistematis. Pengamatan dilakukan oleh guru dan teman sejawat pada waktu peneliti melaksanakan tindakan pembelajaran IPS.

Dalam kegiatan ini peneliti (praktisi), guru dan teman sejawat (obsever) berusaha mengenal dan mendokumentasikan semua indicator baik itu melalui instrument penelitian maupun kamera dari proses hasil perubahan yang terjadi baik yang disebabkan oleh tindakan terencana maupun dampak interverensi dalam pembelajaran IPS berdasarkan metode Inkuiri. Keseluruhan hasil pengamatan direkam dalam bentuk lembar observasi.

Pengamatan dilakukan secara terus menerus mulai dari siklus I sampai dengan siklus II. Pengamatan yang dilakukan pada siklus I dapat mempengaruhi penyusunan tindakan pada siklus selanjutnya. Hasil pengamatan ini kemudian didiskusikan dengan guru dan diadakan refleksi untuk perencanaan siklus berikutnya.

\section{d. Refleksi}

Refleksi diadakan setiap satu tindakan berakhir. Dalam tahap ini peneliti dan observer mengadakan diskusi terhadap tindakan yang dilakukan. Hal-hal yang didiskusikan adalah:

1) Menganalisis tindakan yang baru dilaksanakan

2) Mengulas dan menjelaskan perbedaan rencana dan pelaksanaan tindakan yang telah dilakukan.

3) Melakukan interverensi pemaknaan dan penyimpulan data yang diperoleh. Hasil refleksi bersama ini dimanfaatkan sebagai masukan pada tindakan selanjutnya. Selain itu, hasil kegiatan refleksi setiap tindakan digunakan untuk menyusun simpulan terhadap hasil tindakan siklus I dan II.

\section{Data dan Sumber Data}

\section{Data Penelitian}

Data penelitian tindakan kelas ini berupa hasil pengamatan, dari setiap tindakan penggunaan metode Inkuiri dalam pembelajaran IPS dengan materi masalah sosial pada siswa kelas III UPTD SD Negeri 06 Sialang Kecamatan Kapur IX .

Data tersebut berkaitan dengan perencanaan, pelaksanaan dan hasil pembelajaran yang berupa informasi sebagai berikut :

a. Pelaksanaan pembelajaran yang berhubungan dengan perilaku guru dan siswa yang meliputi interaksi belajar mengajar antara guru dan siswa, siswa dan siswa, siswa dan guru dalam pembelajaran 
b. Evaluasi pembelajaran IPS dengan penggunaan metode inkuiri, yang berupa evaluasi proses maupun evaluasi hasil

c. Hasil tes siswa baik sebelum maupun sesudah pelaksanaan tindakan pembelajaran.

\section{Sumber Data}

Sumber data penelitian ini adalah proses kegiatan pembelajaran IPS dengan penggunaan Metode Inkuiri pada siswa kelas III Sekolah Dasar, yang meliputi perencanaan pembelajaran dan pelaksanaan pembelajaran serta evaluasi pembelajaran. Data diperoleh dari subjek yang diteliti yakni siswa kelas III UPTD SD Negeri 06 Sialang Kecamatan Kapur IX.

\section{Instrumen Penelitian}

Data penelitian ini dikumpulkan dengan menggunakan hasil tes, tes digunakan untuk memperkuat data observasi yang terjadi dalam kelas terutama pada butir penguasaan materi pembelajaran dari unsur siswa.

\section{Analisis Data}

Data yang diperoleh dalam penelitian dianalisis dengan menggunakan analisis data kualitatif yakni analisa data dimulai dengan menelaah sejak pengumpulan data sampai seluruh data terkumpul, tahap analisis tersebut antara lain:

5. Menelaah data yang terkumpul

6. Reduksi data, meliputi pengkategorian dan pengklasifikasian

7. Menyajikan data, dilakukan dengan cara mengorganisasikan data yang telah direduksi

8. Menyimpulkan hasil penelitian dan trigulasi. Kegiatan ini dilakukan dengan cara:
a. Peninjauan kembali catatan lapangan.
b. Bertukar pikiran dengan ahli, teman sejawat dan guru.

Analisis data dilakukan terhadap data yang telah direduksi baik data perencanaan, pelaksanaan, maupun data evaluasi. Analisis data dilakukan dengan cara terpisah-pisah. Hal ini dimaksudkan agar dapat ditemukan berbagai informasi yang spesifik dan terfokus pada berbagai informasi yang mendukung pembelajaran dan yang menghambat pembelajaran. Dengan demikian pengembangan dan perbaikan atas berbagai kekurangan dapat dilakukan tepat pada aspek yang bersangkutan.

Sedangkan model analisa data kuantitatif yaitu terhadap hasil belajar siswa dengan menggunakan pendekatan persentase yang dikemukan oleh Dhydiet (2008:1) dengan rumus sebagai berikut:

$$
\begin{aligned}
& \mathrm{P}=\frac{F}{N} x 100 \% \\
& \text { Keterangan } \\
& \mathrm{P}=\text { Persentase } \\
& \mathrm{F}=\text { Frekuensi responden } \\
& \mathrm{N}=\text { Jumlah responden }
\end{aligned}
$$

Kriteria keberhasilan setiap tindakan adalah $70 \%$. Sesuai dengan pendapat Susanto (2007:41) bahwa standar ketuntasan pembelajaran adalah $70 \%$. Jadi diharapkan keberhasilan yang dicapai adalah $70 \%$.

Data tentang aktivitas guru dan siswa dalam proses belajar mengajar dianalisis dengan menggunakan statistik deskriptif dengan nilai skor rata-rata sebagai berikut:

$$
\begin{aligned}
& 0,00-1,49 \text { sangat kurang } \\
& 1,50-2,49 \text { kurang } \\
& 2,50--3,49 \text { baik } \\
& 3,50 \text {-- 4,49 sangat baik } \\
& \text { 4,50 - 5,00 istimewa }
\end{aligned}
$$

\section{HASIL PENELITIAN DAN PEMBAHASAN Hasil Pembelajaran Pra Siklus}

Pengambilan nilai pra siklus dilaksanakan pada tanggal 2 November 2019 yang diambil dari ulangan harian siswa. Daftar ulangan harian siswa dapat dilihat pada tabel dibawah ini:

Tabel 1 nilai pra siklus siswa

\begin{tabular}{clc}
\hline No & \multicolumn{1}{c}{ Keterangan } & Jumlah \\
\hline 1 & Nilai Rata-rata & 56,11 \\
2 & Siswa yang tuntas belajar & 4 siswa \\
3 & Siswa yang tidak tuntas & 14 siswa \\
4 & Nilai terendah & 45 \\
5 & Nilai Tertinggi & 70 \\
& Persentase ketuntasan & \\
6 & belajar & $22,22 \%$ \\
\hline
\end{tabular}

Dari tabel diatas dapat dilihat bahwa ratarata kelas yang dicapai siswa pada pra siklus mencapai 56,11 dari 18 siswa yang mampu mencapai nilai minimal hanya 4 siswa atau $22,22 \%$. Rendahnya nilai belajar ini maka perlu perbaikan pada siklus selanjutnya dengan menggunakan metode inkuiri. 


\section{Hasil Penelitian Siklus}

\section{Siklus I Pertemuan 1}

a. Perencanaan

Materi pembelajaran yang dilaksanakan pada siklus I pertemuan 1 adalah pembelajaran tentang masalah sosial yang peneliti fokuskan pada kemiskinan dan masalah lingkungan hidup dengan menggunakan metode inkuiri. Standar Kompetensinya yaitu mengenal sumber daya alam, kegiatan ekonomi, dan kemajuan teknologi di lingkungan kabupaten/ kota dan provinsi, sedangkan Kompetensi dasar yang ingin dicapai pada materi ini adalah mengenal permasalahan sosial di daerahnya.

Adapun Indikator yang ingin dicapai pada siklus I pertemuan 1 ini adalah:

1) menentukan suatu masalah yang ada di daerah setempat,

2) menentukan hipotesa suatu masalah yang terdapat didaerah setempat,

3) mengidentifikasi masalah sosial di daerah setempat .

Pada pertemuan 1 dilaksanakan semua langkah inkuiri yang terdiri dari 5 langkah dimulai dari langkah mengenali dan menjelaskan masalah, pembentukan hipotesa, mengumpulkan data, menganalisa data untuk menguji hipotesa, menarik kesimpulan. Begitu juga dengan pertemuan 1 juga dilaksanakan semua langkah inkuiri guna melihat keberhasilan dari metode inkuiri.

b. Pelaksanaan

Pada kegiatan pembelajaran ini peneliti bertindak sebagai guru. Pertemuan 1 ini dilaksanakan pada hari tanggal 9 November 2019.

Pelaksanaan pembelajaran pertemuan 1 pada penelitian ini melalui 3 tahap kegiatan yakni kegiatan awal (Pendahuluan), kegiatan inti (Pelaksanaan), kegiatan akhir (Penutup). Yang Pelaksanaannya dapat diuraikan sbagai berikut:

\section{Siklus I Pertemuan 2}

a. Perencanaan

Pada siklus I pertemuan 2 ini peneliti masih membahas tentang masalah sosial yang peneliti fokuskan pada kemiskinan dan masalah sosial seperti halnya pertemuan 1 , hanya saja pada pertemuan 2 materi yang diajarkan merupakan materi lanjutan dari pertemuan I yang tentunya dengan menggunakan metode inkuiri. Dan sama halnya dengan pertemuan I Standar Kompetensinya yaitu mengenal sumber daya alam, kegiatan ekonomi, dan kemajuan teknologi di lingkungan kabupaten/ kota dan provinsi, sedangkan Kompetensi dasar yang ingin dicapai pada materi ini adalah mengenal permasalahan sosial di daerahnya.

Sedangkan Indikator yang ingin dicapai pada siklus I pertemuan 2 ini adalah:

1) menceritakan penyebab timbulnya masalah sosial yang ada di daerah setempat,

2) menjelaskan akibat yang ditimbulkan dari masalah sosial yang ada di daerah setempat,

3) menjelaskan cara mengatasi masalah sosial yang ada di tempat mereka tinggal.

b. Pelaksanaan Tindakan

Pelaksanaan pertemuan 2 ini pada tanggal 16 November 2019. Saat melaksanakan pembelajaran pada pertemuan 2 ini penelitian juga melalui 3 tahap yakni tahap awal, tahap inti, tahap akhir. Dan di tahap intil inilah dilaksanakan langkah-langkah metode inkuiri yaitu mengenali dan menjelaskan masalah, pembentukan hipotesa, mengumpulkan data, menganalisa data untuk menguji hipotesa, menarik kesimpulan sesuai dengan rancangan yang telah dibuat dalam RPP.

\section{Pengamatan Tindakan Siklus I}

Pada tahap ini pengamatan dilakukan oleh observer, yaitu peneliti sebagai pratisi dan dibantu teman sejawat yang bertugas sebagai pengamat, mengamati aktivitas praktisi dalam pembelajaran dengan menggunakan lembar observasi guru dan siswa.

Berdasarkan data observasi yang dilakukan oleh seorang pengamat terhadap aktivitas guru dari 22 aspek pengamatan diperoleh skor 76, dengan demikian nilai rata-rata adalah 3,45. Berarti taraf keberhasilan aktivitas guru berdasarkan observasi pengamat termasuk dalam kategori baik.

Berdasarkan hasil pengamatan aktivitas siswa selama pembelajaran IPA dengan menggunakan metode inkuiri, dari 20 aspek pengamatan, diperoleh skor 49 . Sedangkan nilai rata-rata yang diperoleh secara keseluruhan terhadap aktivitas siswa selama pembelajaran IPS dengan menggunakan metode inkuiri yaitu 2,45 . Dengan begitu taraf keberhasilan aktivitas 
siswa berdasarkan observasi pengamat termasuk pada kategori kurang, maka perlu perbaikan dalam proses belajar mengajar dengan menggunakan metode inkuiri yang lebih baik lagi.

Setelah kegiatan pada siklus I dilakukan, maka diadakan tes untuk mengetahui kemampuan siswa menguasai materi yang diajarkan pada pembelajaran IPS dengan menggunakan metode inkuiri. Nilai yang diperoleh siswa dapat dilihat pada tabel berikut ini:

Tabel 2. Nilai Siswa siklus I

\begin{tabular}{clc}
\hline No & \multicolumn{1}{c}{ Keterangan } & Jumlah \\
\hline 1 & Nilai Rata-rata & 70,83 \\
2 & Siswa yang tuntas belajar & 10 siswa \\
3 & Siswa yang tidak tuntas & 8 siswa \\
4 & Nilai terendah & 60 \\
5 & Nilai Tertinggi & 80 \\
& Persentase ketuntasan & $55,56 \%$ \\
6 & belajar
\end{tabular}

Berdasarkan tabel di atas menunjukkan jumlah siswa yang mencapai ketuntasan belajar secara individu sebanyak 10 siswa atau 55,46\%. Rata-rata hasil belajar yang diperoleh siswa adalah 70,83 dan secara umum sudah mencapai atau memenuhi KKM namun masih ada siswa yang belum tuntas atau mencapai yang ditentukan oleh UPTD SD Negeri 06 Sialang Kecamatan Kapur IX yaitu minimal yaitu 70 pada pembelajaran IPS,maka hasil belajar siswa pada pembelajaran IPS untuk siklus I belum mencapai ketuntasan belajar klasikal.

\section{Refleksi}

Refleksi adalah kegiatan untuk mengingat dan melihat kembali pada tiap-tiap siklus untuk menyempurnakan pada siklus berikutnya. Dengan demikian hasil data yang diperoleh dari siklus I diuraikan sebagai berikut:

a. Aktivitas Guru

Secara umum, aktivitas guru dalam proses belajar mengajar pada siklus I dalam menerapkan metode pembelajaran inkuiri pada pembelajaran IPS di kelas III UPTD SD Negeri 06 Sialang sudah baik, akan tetapi ada 2 apek pengamatan yang harus di tingkatkan lagi khususnya pada saat guru mengkondisikan siswa dalam beberapa kelompok, dan kemampuan guru ketika membimbing siswa dalam kelompok. Hal ini disebabkan pada saat membagi murid dalam beberapa kelompok ada siswa yang tidak senang dengan anggota kelompok pilihan guru, dan ketika kerja kelompok ada beberapa kelompok yang tidak bekerjasama dan ada beberapa siswa yang mengganggu temannya yang lain. Oleh karena itu, kemampuan guru pada aspek-aspek tersebut perlu ditingkatkan.

b. Aktivitas Siswa

Aktivitas siswa dalam proses belajar mengajar pada siklus I masih kurang. Siswa masih kurang serius dalam mendengar dan memperhatikan arahan serta penjelasan guru, siswa juga kurang serius saat melakukan percobaan, dan tidak saling berkomunikasi antar teman kelompok. Hal ini disebabkan karena siswa belum terbiasa dengan pembelajaran yang diterapkan guru dengan menggunakan metode inkuiri sehingga sebagian siswa terlalu asik dengan media yang sudah dibagikan oleh guru, siswa kurang terbiasa berdiskusi dalam kelas sebelum proses pembelajaran dengan menggunakan metode inkuiri. Oleh karena itu, perlu dilakukan revisi dan perbaikan-perbaikan terhadap metode inkuiri pada pembelajaran IPS untuk siklus selanjutnya.

\section{c. Hasil Belajar}

Persentase ketuntasan belajar siswa masih berada di bawah 70\%, maka hasil belajar siswa pada pembelajaran IPA untuk siklus I belum mencapai ketuntasan belajar klasikal. Dengan demikian, peneliti harus melakukan siklus II untuk memperbaiki kekurangan-kekurangan yang ada pada siklus I. Berdasarkan refleksi pada siklus pertama, maka guru dan pengamat menetapkan bahwa tindakan yang akan dilaksanakan pada siklus kedua perlu ditingkatkan agar pembelajaran berlangsung secara optimal.

\section{Hasil Penelitian Siklus II}

\section{Perencanaan}

Penggunaan metode inkuiri dalam perencanaan pembelajaran IPS disusun dan diwujudkan dalam bentuk rancangan pembelajaran model Rencana Pelaksanaan Pembelajaran (RPP). Perencanaan yang dibuat pada siklus II pada garis besarnya sama dengan perencanaan pembelajaran siklus I. Perbedaanya dapat dilihat dari materi, karena materi yang diajarkan pada siklus II ini merupakan materi 
lanjutan dari siklus I. Indikator yang ingin dicapai pada siklus II ini adalah:

a. menentukan suatu masalah yang terdapat pada gambar,

b. menentukan hipotesa suatu masalah yang terdapat pada gambar,

c. mengidentifikasi masalah sosial di daerah setempat.

\section{Pelaksanaan Tindakan}

Siklus dilaksanakan dalam dua kali pertemuan. Pertemuan 1 dilaksanakan pada tanggal 23 November 2019, dan pertemuan ke 2 dilaksanakan pada tanggal 30 November 2019. Karena materi pada pertemuan 1 panjang dan waktu tidak mencukupi, maka tes tertulis dilakukan pada petemuan ke 2. Pembelajaran pada penelitian ini melalui tiga tahapan, yaitu kegiatan pendahuluan, kegiatan inti, kegiatan akhir sesuai dengan rancangan yang telah dibuat dalam RPP.

\section{Pengamatan Siklus II}

Sama seperti siklus sebelumnya, pengamat bertugas mengamati aktivitas praktisi dalam pembelajaran dengan menggunakan lembar observasi guru dan siswa. Kemudian dalam proses penelitian peneliti juga dibantu oleh satu teman lainnya yang bertugas mendokumentasikan semua langkah-langkah pembelajaran yang peneliti lakukan selama menjadi guru praktisi dalam proses pembelajaran.

Hasil pengamatan aktivitas guru dalam pelaksanaan belajar mengajar IPS pada siklus II diperoleh skor 90 dengan nilai rata- rata adalah 4,09 dan taraf keberhasilan aktivitas guru berdasarkan observasi pengamat termasuk dalam kategori sangat baik.

Dengan demikian, kemampuan guru dalam melaksanakan pembelajaran pada siklus II terjadi peningkatan. Aspek- aspek yang diamati dalam pembelajaran pada siklus II dilaksanakan dengan baik. Pada siklus I kemampuan guru dalam pelaksanaan belajar mengajar masih tergolong kategori baik, dan pada siklus II termasuk pada kategori sangat baik, sehingga hasil yang diharapkan telah maksimal.

Berdasarkan hasil pengamatan aktivitas siswa selama pembelajaran IPA dengan menggunakan metode inkuiri, dari 20 aspek pengamatan, diperoleh skor 70 . Sedangkan nilai rata-rata yang diperoleh secara keseluruhan terhadap aktivitas siswa selama pembelajaran IPS dengan menggunakan metode inkuiri yaitu 3,5. Dengan begitu taraf keberhasilan aktivitas siswa berdasarkan observasi pengamat termasuk pada kategori sangat baik, maka perlu perbaikan dalam proses belajar mengajar dengan menggunakan metode inkuiri yang lebih baik lagi.

Setelah kegiatan pada siklus II dilakukan, maka diadakan tes untuk mengetahui kemampuan siswa menguasai materi yang diajarkan pada pembelajaran IPS dengan menggunakan metode inkuiri. Nilai yang diperoleh siswa dapat dilihat pada tabel berikut ini:

Tabel 3 Nilai Siswa siklus II

\begin{tabular}{clc}
\hline No & \multicolumn{1}{c}{ Keterangan } & Jumlah \\
\hline 1 & Nilai Rata-rata & 80,83 \\
2 & Siswa yang tuntas belajar & 18 siswa \\
3 & Siswa yang tidak tuntas & 0 siswa \\
4 & Nilai terendah & 70 \\
5 & Nilai Tertinggi & 90 \\
& Persentase & \\
6 & belajar ketuntasan & $100,00 \%$ \\
\hline
\end{tabular}

Berdasarkan tabel di atas menunjukkan jumlah siswa yang mencapai ketuntasan belajar secara individu sebanyak 18siswa atau $100 \%$ denag rata-rata hasil belajar yang diperoleh siswa adalah 80,83. Untuk siklus II sudah tercapaiketuntasan belajar klasikal secara maksimal.

\section{Refleksi}

Pada siklus II ini ternyata sudah tidak perlu perbaikan lagi, sebab dengan adanya penggunaan metode inkuiri pada pembelajaran IPS, maka kemampuan yang dimiliki siswa pada materi masalah sosial menjadi meningkat dan kreatifitas pola pikir siswa menjadi lebih baik lagi serta ketuntasan belajar siswa pada pelajaran IPS lebih maksimal. Setelah kegiatan pada siklus II dilakukan, maka diadakan tes untuk mengetahui kemampuan siswa dalam menguasai pembelajaran IPS dengan menggunakan metode inkuiri. Dari hasil tes menunjukkan jumlah siswa yang mencapai ketuntasan belajar secara individu sebanyak 18 siswa atau $100 \%$ denag rata-rata hasil belajar yang diperoleh siswa adalah 80,83.Untuk siklus II sudah tercapaiketuntasan belajar klasikal secara maksimal. 


\section{Pembahasan}

\section{Aktivitas guru selama pembelajaran}

Penelitian ini adalah penelitian tindakan kelas yang dilakukan untuk mengetahui ada tidaknya peningkatan kemampuan siswa kelas UPTD III SD Negeri 06 Sialang melalui penerapan metode inkuiri pada pembelajaran IPS.

Berdasarkan pengamatan pada siklus I diketahui bahwa pada aspek kegiatan aktivitas guru dalam menerapkan pembelajaran IPA dengan menggunakan metode inkuiri memperoleh skor 76, sedangkan nilai rata-rata secara keseluruhan terhadap kemampuan guru adalah 3,45 dan termasuk kategori baik.

Pada siklus II, dapat diketahui bahwa pada aspek kegiatan aktivitas guru selama melaksanakan pembelajaran memperoleh skor 90, sedangkan nilai rata-rata secara keseluruhan terhadap kemampuan guru dalam melakukan proses belajar mengajar IPS dengan menggunakan metode inkuiri adalah 4,09 dan termasuk kategori sangat baik.

Dengan demikian, kemampuan guru dalam melaksanakan pembelajaran pada siklus II terjadi peningkatan. Aspek- aspek yang diamati dalam pembelajaran pada siklus II dilaksanakan dengan baik, sehingga hasil yang diharapkan telah maksimal. Pada siklus II ini ternyata sudah tidak perlu perbaiki lagi, sebab dengan adanya penggunaan metode inkuiri pada pembelajaran IPS, maka kemampuan yang dimilki siswa pada materi masalah sosial menjadi meningkat dan kreatifitas pola pikir siswa menjadi lebih baik lagi serta ketuntasan belajar siswa pada pelajaran IPA lebih maksimal

\section{Aktivitas Siswa selama pembelajaran}

Pada siklus I hasil data penelitian aktivitas siswa pada pertemuan pertama memperoleh skor 49 dengan rata- rata 2,45 (nilai berada pada kategori kurang), namun setelah adanya siklus II skor yang dicapai yaitu 70 dengan rata-rata 3,50 (nilai berada pada kategori sangat baik).

Data hasil observasi terhadap aktivitas belajar siswa terjadi peningkatan dari siklus I, dan pada siklus II. Kenaikan nilai aktivitas siswa disebabkan siswa telah memahami pembelajaran IPS dengan menggunakan metode inkuiri berjalan dengan baik.
Berdasarkan data tersebut, maka dapat disimpulkan bahwa penerapan metode inkuiri pada pembelajaran IPA dapat meningkatkan kemampuan hasil belajar siswa kelas III UPTD SD Negeri 06 Sialang Kecamatan Kapur IX.

\section{Hasil Belajar Siswa}

Untuk mengetahui siswa telah mencapai ketuntasan hasil belajar maka dilakukan tes. Pemberian tes dilakukan dua kali diantaranya tes siklus I dan tessiklus II. Namun sebelum dilakukan nya penelitian diambilah nilai awal yang disebut dengan pra siklus.

Dari hasil analisis dimana diperoleh hasil yang sangat memuaskan, yaitu terjadi peningkatan hasil belajar siswa pada setiap siklusnya. Pada pra siklus jumlah siswa yang mencapai $\mathrm{KKM}$ adalah $22,22 \%$ atau hanya 4 siswa saja. Pada siklus I dengan metode inkuiri jumlah siswa yang mencapai KKM adalah 10 orang siswa dengan jumlah 55,56\% dengan ratarata 70,83 . Hasil belajar siswa sangat meningkat pada siklus II yaitu 18 orang siswa atau $100 \%$ yang tuntas mempelajari materi masalah sosial dengan metode inkuiri dengan rata-rata 80,83.

\section{KESIMPULAN}

Dari paparan dan hasil penelitian dan pembahasan dalam Bab IV, simpulan yang dapat diambil dari penelitian ini adalah sebagai berikut:

Terjadi peningkatan hasil belajar siswa pada setiap siklusnya. Pada pra siklus jumlah siswa yang mencapai KKM adalah $22,22 \%$ atau hanya 4 siswa saja. Pada siklus I dengan metode inkuiri jumlah siswa yang mencapai $\mathrm{KKM}$ adalah 10 orang siswa dengan jumlah 55,56\% dengan rata-rata 70,83. Hasil belajar siswa sangat meningkat pada siklus II yaitu 18 orang siswa atau $100 \%$ yang tuntas mempelajari materi masalah sosial dengan metode inkuiri dengan rata-rata 80,83. Aktivitas guru yang berlangsung pada siklus I diperoleh skor 76 dengan rata-rata 3,45 tergolong dalam kategori baik, sedangkan pada siklus II mengalami peningkatan dengan skor 90 dan rata-rata 4,09 tergolong dalam kategori sangat baik. Aktivitas siswa selama kegiatan belajar mengajar berlangsung pada siklus I memperoleh skor 49 dengan rata-rata 2,45 termasuk dalam kategori kurang, sedangkan pada siklus II mengalami 
peningkatan dengan skor 70 dan rata-rata 3,50 tergolong dalam katagori sangat baik

\section{DAFTAR RUJUKAN}

Depdiknas, 2006. Kurikulum Tingkat Satuan

Pendidikan. Jakarta: Depdiknas

Depdiknas, 2006. Panduan Penyusunan

Kurikulum Tingkat Satuan Pendidikan

Jenjang Pendidikan Dasar dan Menengah.

Jakarta: Depdiknas

Ischak SU, dkk.1997. Pendidikan IPS di SD.

Jakarta: Departemen Pendidikan dan

Kebudayaa

Kunandar. 2008. Guru Profesional. Jakarta: PT Raja Grafindo Persada

Moedjiono. 1993. Strategi Belajar Mengajar. Jakarta: Depatemen Pendidikan dan Kebudayaan

Mulyani, S, U, dkk. 1999. Strategi Belajar Mengajar. Jakarta: Departemen Pendidikan Dan Kebudayaan

Nana, S. 1995. Dasar- Dasar Pembelajaran. Bandung: Sinar Baru Algensindo

Ngalim, P. 1996. Evaluasi Pendidikan dan Pembelajaran. Bandung: Remaja Rosdakarya

Nurhadi. Dkk. 2002. Pembelajaran Kontestual(Contextual Teaching And Learning/ CTL) dan Penerapannya dalam $K B K$. Malang. Universitas Negeri Malang.

Oemar, H. 2008. Proses Belajar Mengajar. Jakarta: PT. Bumi Aksara

Ritawati, M, dkk.2007. Hand Out Mata Kuliah Metodologi Penelitian Tindakan Kelas. Padang: UNP

Udin S. Winata Putra. 2002. Materi dan Pembelajaran IPS SD. Universitas

Wina, S. 2008. Strategi Pembelajaran Berorientasi Standar Proses Pendidikan. Jakarta: Kencana. 